\title{
Hydrological controls on DOC : nitrate resource stoichiometry in a lowland, agricultural catchment, southern UK
}

\author{
Catherine M. Heppell ${ }^{1}$, Andrew Binley ${ }^{2}$, Mark Trimmer ${ }^{3}$, Tegan Darch ${ }^{1,2,4}$, Ashley Jones ${ }^{1,2}$, Ed Malone ${ }^{1,2}$, \\ Adrian L. Collins ${ }^{4}$, Penny J. Johnes ${ }^{5}$, Jim E. Freer ${ }^{5}$, and Charlotte E. M. Lloyd ${ }^{6}$ \\ ${ }^{1}$ School of Geography, Queen Mary University of London, Mile End Road, London, E1 4NS, UK \\ ${ }^{2}$ Lancaster Environment Centre, Lancaster University, Lancaster, LA1 4YQ, UK \\ ${ }^{3}$ School of Biological and Chemical Sciences, Queen Mary University of London, Mile End Road, London, E1 4NS, UK \\ ${ }^{4}$ Sustainable Agriculture Sciences Department, Rothamsted Research, North Wyke, Okehampton, EX20 2SB, UK \\ ${ }^{5}$ School of Geographical Sciences, University of Bristol, University Road, Bristol, BS8 1SS, UK \\ ${ }^{6}$ School of Chemistry, University of Bristol, Cantock's Close, Bristol, BS8 1TS, UK \\ Correspondence to: Catherine M. Heppell (c.m.heppell@qmul.ac.uk)
}

Received: 19 January 2017 - Discussion started: 7 March 2017

Revised: 10 July 2017 - Accepted: 27 July 2017 - Published: 27 September 2017

\begin{abstract}
The role that hydrology plays in governing the interactions between dissolved organic carbon (DOC) and nitrogen in rivers draining lowland, agricultural landscapes is currently poorly understood. In light of the potential changes to the production and delivery of DOC and nitrate to rivers arising from climate change and land use management, there is a pressing need to improve our understanding of hydrological controls on DOC and nitrate dynamics in such catchments. We measured DOC and nitrate concentrations in river water of six reaches of the lowland river Hampshire Avon (Wiltshire, southern UK) in order to quantify the relationship between BFI (BFI) and DOC : nitrate molar ratios across contrasting geologies (Chalk, Greensand, and clay). We found a significant positive relationship between nitrate and BFI $(p<0.0001)$, and a significant negative relationship between DOC and BFI $(p<0.0001)$, resulting in a non-linear negative correlation between DOC: nitrate molar ratio and BFI. In the Hampshire Avon, headwater reaches which are underlain by clay and characterized by a more flashy hydrological regime are associated with DOC: nitrate ratios $>5$ throughout the year, whilst groundwater-dominated reaches underlain by Chalk, with a high BFI have DOC: nitrate ratios in surface waters that are an order of magnitude lower $(<0.5)$. Our analysis also reveals significant seasonal variations in DOC : nitrate transport and highlights critical periods of nitrate export (e.g. winter in sub-catchments underlain by Chalk and Greensand, and autumn in drained, clay sub-
\end{abstract}

catchments) when DOC: nitrate molar ratios are low, suggesting low potential for in-stream uptake of inorganic forms of nitrogen. Consequently, our study emphasizes the tight relationship between DOC and nitrate availability in agricultural catchments, and further reveals that this relationship is controlled to a great extent by the hydrological setting.

\section{Introduction}

As we enter the Anthropocene, the increase in nitrogen (N) concentrations in the natural environment, arising from the combined effects of agricultural intensification and fossil fuel use, is causing pressing environmental problems (Vitousek et al., 1997; Carpenter et al., 1998; Galloway and Cowling, 2002; Rabalais, 2002). An increase in concentrations and loads of nitrate in freshwater environments is one such issue arising from diffuse agricultural pollution, often correlated with the eutrophication of coastal areas (Billen et al., 2011; Parliamentary Office of Science and Technology, 2014; Howarth et al., 2012; Vitousek et al., 2009; Withers et al., 2014). Furthermore, in permeable geologies, responses to land management initiatives targeted at reducing nitrate loading are delayed due to long water residence times, with little effect seen in some groundwater-fed catchments over decadal timescales (Howden et al., 2011; Tesoriero et al., 2013; Wang et al., 2012, 2013, 2016). In the United States, 
a legacy of accumulated nitrate in heavily managed, agricultural catchments has been associated with temporal invariance of annual flow-weighted concentration (a biogeochemical export regime termed chemostatic) irrespective of the permeability of the geology and soil type (Basu et al., 2010). These managed catchments are considered to be transport limited with regards to nitrate, meaning that solute export is controlled predominantly by hydrology rather than biogeochemistry (Basu et al., 2011). Thus changing climate, with important, potential implications for rainfall patterns and hydrochemical responses in rivers, is adding a new urgency to understanding and managing the issue of excess nitrate in our agricultural-dominated landscapes (Howarth et al., 2012). In the UK, there is concern that warmer, drier summers and wetter winters may lead to increased nitrate export from lowland catchments (Whitehead et al., 2009), one scenario being an increased accumulation of nitrate in soils by mineralization in hot, dry summers followed by flushing of nitrate from soils during autumn at the end of the drought (Whitehead et al., 2006) especially in conjunction with first-flush responses (Jiang et al., 2010; Yang et al., 2015; Orr et al., 2016). However, considerable uncertainty exists around current predictions (Heathwaite, 2010), and policymakers lack results from studies at appropriate temporal and spatial scales for confident decision making (Watts et al., 2015).

Over the last decade, there has also been an increasing awareness of the significance of the transport and transformation of carbon in fluvial systems within the overall conceptualization of the global carbon cycle, and freshwaters are now recognized as critical contributors to global carbon fluxes (Dagg et al., 2004; Beusen et al., 2005; Battin et al., 2009). In addition, there is an increased understanding that establishing the factors that control water-borne carbon fluxes is key to predicting the likely implications of climate change for patterns and magnitude of organic carbon transport through freshwaters (Aitkenhead and McDowell, 2000). Although dissolved organic carbon (DOC) plays a crucial role in stream ecology (influencing processes such as nutrient uptake and the balance between heterotrophy and autotrophy) our understanding of terrestrial-to-aquatic transfers, aquatic processing of DOC, and its character in lowland, agricultural streams is incomplete (Aubert et al., 2013; Stanley et al., 2012; Yates et al., 2016), as much of the effort in this area has been focused o forested catchments, boreal peatlands, and/or upland landscapes with significant wetland cover (Frost et al., 2006; Ågren et al., 2007).

Macronutrients are not cycled in isolation, and important ecological consequences arise from their interplay (Dodds et al., 2004); a key focus of current research is on the linkage between essential nutrients such as carbon (C) and nitrogen (N). Although these elements exist in many forms in river systems, the most abundant biologically available form of the compounds in lowland, intensively farmed catchments are likely to be DOC and nitrate (Taylor and Townsend, 2010) with nitrate typically contributing $>70 \%$ of the total dis- solved N species (Durand et al., 2011). The speciation of N in lowland agricultural catchments in Europe has been reported previously (see Durand et al., 2011), including in one of the sub-catchments (River Wylye) that is a component of this study (Yates and Johnes, 2013; Yates et al., 2016), but without comparison to the simultaneous behaviour of DOC. This paper therefore focuses on both nitrate and DOC, as the availability of DOC in a stream ecosystem may influence both the quantity and speciation of $\mathrm{N}$ exported downstream (Goodale et al., 2005; Bernhardt and Likens, 2002; Grebliunas and Perry, 2016). Taylor and Townsend (2010) synthesized global datasets for DOC: nitrate ratios from groundwater to the open ocean, and hypothesized that an observed threshold ratio of around 4 was indicative of the shift in carbon to $\mathrm{N}$ limitation in rivers representative of the stoichiometric demands of microbial anabolism. Taylor and Townsend (2010) suggested that, at low DOC: nitrate ratios, the extent of nitrate accrual in global waters may be restricted by the rapid conversion of nitrate to nitrogen $\left(\mathrm{N}_{2}\right)$ gas via denitrification, whereas at high DOC: nitrate ratios heterotrophic $\mathrm{N}$ assimilation may strongly reduce in-stream nitrate concentrations. Whole-stream nutrient additions to rivers characterized by varying land use (using the "Tracer Additions As Spiralling Curve Characterization" methodology) have provided experimental evidence that DOC : nitrate ratios are strongly positively correlated with the rate of whole-stream nitrate removal (see results from Mulholland et al., 2015, presented in Fig. 7 of Rodríguez-Cardona et al., 2016), although such experiments cannot distinguish between nitrate removal via assimilation and/or denitrification mechanisms. In summary, there is a need to understand whether monitoring DOC : nitrate ratios in rivers could prove a useful component of a toolkit for adaptive nitrate management of river catchments in response to, for example, land use or climate change.

Controls on riverine DOC and nitrate arise from a combination of terrestrial accumulation, transfer to the river, and in-stream transformations (Stanley et al., 2012). The transfer of DOC and nitrate from terrestrial sources to the channel by hydrological mechanisms results in changing relationships between concentration and river discharge, often described by a power function $\left(C=a Q^{b}\right.$, where $C$ is concentration and $Q$ is discharge) which can exhibit marked intra-annual dynamics (Oeurng et al., 2011; Morel et al., 2009; Basu et al., 2010; Outram et al., 2014). Therefore, integrated annual measurements risk masking important seasonal patterns in terrestrial-to-aquatic transfers and export of DOC and nitrate, arising from variations in hydrological pathways throughout the year, such as the interplay between groundwater and shallower lateral flows due to wetting-up of upper soil horizons in response to autumn rain (Prior and Johnes, 2002; Sandford et al., 2013; Outram et al., 2014; Yates and Johnes, 2013). Such intra-annual variations in solute chemistry have been termed the "hydrochemical signature" of the catchment (Aubert et al., 2013). This hydrochemical signature is espe- 
cially important to consider across an agricultural landscape characterized by a wide range of baseflow index (BFI). We might hypothesize that groundwater-dominated areas (characterized by a high BFI) will exhibit a stable, more damped, hydrochemical response throughout the year, whereas subcatchments of low BFI might exhibit a wider range of nitrate and DOC concentration arising from varying contributions of rapid hydrological pathways (i.e. quickflow). Thus, here we aim to develop a spatio-temporal understanding of the processes controlling loading of DOC and nitrate to a lowland, agricultural catchment (Hampshire Avon, UK), which is essential for understanding and managing their combined ecological impact. Furthermore, as our study took place during a period of drought and subsequent flooding in the UK, a focus on seasonality may help to identify any critical periods of nutrient export under future climate change scenarios of drier summers and wetter winters.

To summarize, our research objectives were as follows:

i. To quantify the relationship between nitrate, DOC, and DOC: nitrate molar ratio with BFI for six subcatchments of contrasting geology (Chalk, Greensand, and clay) in the Hampshire Avon.

ii. To assess the intra-annual variations in contributions of groundwater and quickflow to streamflow across three sub-catchments representing high, intermediate, and low baseflow index, and to establish the extent to which nitrate and DOC transport in the catchment arises from the interplay between groundwater and quickflow components.

iii. To assess the potential implications of any spatiotemporal variations in DOC: nitrate ratios for future $\mathrm{N}$ management.

\section{Materials and methods}

\subsection{Site description}

The research was undertaken at six river reaches in the Hampshire Avon upstream of Salisbury (Wiltshire, UK), representing sub-catchments of contrasting geology (clay, Greensand, and Chalk), and a gradient of BFI (Fig. 1; Table 1). The majority of the upper catchment of the Hampshire Avon (draining ca. $1390 \mathrm{~km}^{2}$ in total) is dominated by the Cretaceous Chalk geology, and the hydrogeological properties of these geological units are described in detail in Allen et al. (2014). Sites CW on the River Wylye and CE on the river Ebble are river reaches characterized by high baseflow indices $(>0.9)$ where Chalk provides the main source of groundwater (Allen et al., 2014). In the north and west of the Hampshire Avon catchment there are also significant groundwater contributions from geological formations of Upper Greensand which comprise fine-grained glauconitic sands

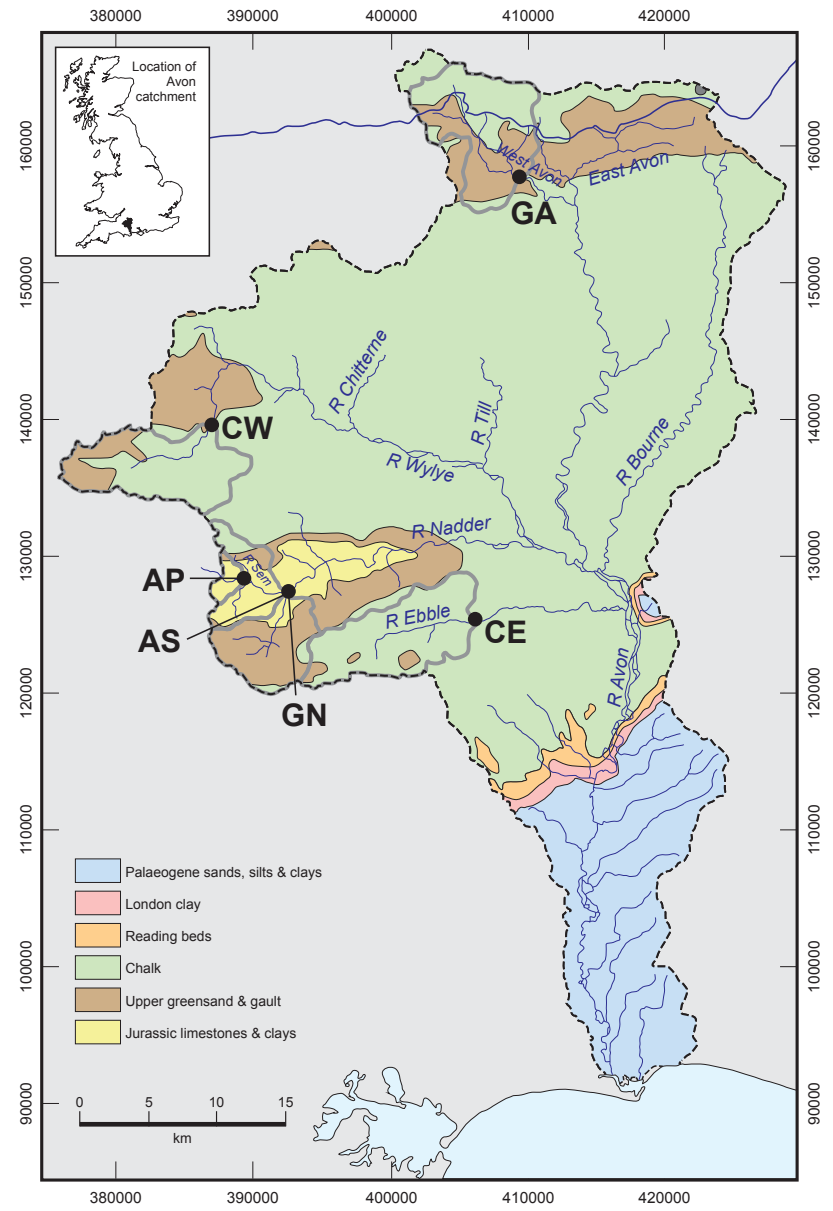

Figure 1. Catchment map of the Hampshire Avon showing study sites and geology. Grey lines indicate sub-catchment boundaries delineated by topography.

and sandstones (Bristow et al., 1999). The sub-catchments of sites GN on the river Nadder in the west of the catchment, and GA in the north of the catchment, both comprised ca. $50 \%$ Upper Greensand by area with BFI of 0.695 and 0.861 , respectively. The two sites characterized by the lowest BFI, sites AS (0.372) and AP (0.234), are located in the sub-catchment of the river Sem underlain by impermeable Late Jurassic Kimmeridge Clay (usually a non-aquifer) and thin interbedded limestone from which limited groundwater flow may occur (Allen et al., 2014). Agricultural land use dominates the Hampshire Avon catchment with arable farming including horticulture comprising $42 \%$ of land use, and improved grassland for dairy and beef production covering $23 \%$ of the catchment. The distribution of arable and livestock farming varies with sub-catchment; improved grassland dominates in the clay catchment of the river Sem (AS and AP), where it supports intensive dairy production, whilst arable agriculture represents ca. $50 \%$ of land use at the chalk sites (CW and $\mathrm{CE}$ ), with sheep grazing and intensive pig production as minority land uses (Table 1). 
Table 1. Hydrological characteristics of the six sub-catchments in the Hampshire Avon.

\begin{tabular}{|c|c|c|c|c|c|c|c|}
\hline $\begin{array}{l}\text { Site } \\
\text { code }\end{array}$ & Major geology & River & Stream order ${ }^{a}$ & $\begin{array}{l}\text { Catchment } \\
\text { size }\left(\mathrm{km}^{2}\right)\end{array}$ & $\mathrm{BFI}^{\mathrm{b}}$ & BFIHOST $^{\mathrm{c}}$ & Major land use $\mathrm{d}^{\mathrm{d}}$ \\
\hline AP & Clay $(>99 \%)$ & Sem & $1(73 \%), 2(18 \%), 3(9 \%)$ & 4.9 & 0.207 & 0.234 & $\begin{array}{l}\text { Arable }(5 \%), \\
\text { grassland }(95 \%)\end{array}$ \\
\hline AS & Clay $(74 \%)$ & Sem & $1(54 \%), 2(26 \%), 3(20 \%)$ & 26.0 & 0.549 & 0.372 & $\begin{array}{l}\text { Arable }(10 \%), \\
\text { grassland }(90 \%)\end{array}$ \\
\hline GN & Greensand $(52 \%)$ & Nadder & $1(58 \%), 2(39 \%), 3(3 \%)$ & 34.6 & 0.781 & 0.695 & $\begin{array}{l}\text { Arable }(46 \%) \text {, } \\
\text { grassland }(33 \%)\end{array}$ \\
\hline GA & Greensand $(50 \%)$ & W Avon & $1(47 \%), 2(31 \%), 3(22 \%)$ & 59.2 & 0.744 & 0.861 & $\begin{array}{l}\text { Arable }(25 \%) \text {, } \\
\text { grassland }(50 \%)\end{array}$ \\
\hline $\mathrm{CE}$ & Chalk $(96 \%)$ & Ebble & $1(28 \%), 2(72 \%)$ & 58.9 & 0.906 & 0.953 & $\begin{array}{l}\text { Arable }(55 \%) \text {, } \\
\text { grassland }(32 \%)\end{array}$ \\
\hline $\mathrm{CW}$ & Chalk $(80 \%)$ & Wylye & $1(60 \%), 2(40 \%)$ & 53.5 & 0.901 & 0.931 & $\begin{array}{l}\text { Arable }(50 \%), \\
\text { grassland }(35 \%)\end{array}$ \\
\hline
\end{tabular}

${ }^{a}$ Strahler stream order with \% contribution of stream order to the network and stream order at site in bold; ${ }^{b}$ BFI calculated using discharge data collected from July 2013 to 2014; ${ }^{\mathrm{c}}$ BFI calculated using the UK Hydrology of Soil Types (HOST) classification; ${ }^{\mathrm{d}}$ major land use based on 2010 June Agriculture Survey (JAS) data.

\subsection{Field instrumentation}

Sites AS, GA, GN, and CE were instrumented for 2 years from June 2013 until June 2015. Stream stage was measured using pressure transducers (HOBO U20-001-01, Onset Corporation, USA, at AS, GA and GN; Levelogger Edge, Solinst, Canada, at CE) in a perforated stilling well, logging at 15-mins intervals. Regular (fortnightly when possible) manual measurements of discharge by the velocityarea method enabled construction of stage-discharge relationships for each site. Discharge values used in the analysis were scaled to $\mathrm{mm} \mathrm{day}^{-1}$, using an assumed catchment area defined by the topographic divide for that point in the stream network. Rainfall was measured at 15 min intervals at AS, GA, and CE using a tipping bucket rain gauge $(674$, Teledyne Isco, USA) in order to calculate daily rainfall totals $\left(\mathrm{mm} \mathrm{day}^{-1}\right)$ for the study period. Details of exact locations of hydrological measurements can be found in Heppell et al. (2016a, b).

Temperature, $\mathrm{pH}$, dissolved oxygen (optical), and electrical conductivity of river water were logged in situ at $30 \mathrm{~min}$ intervals using a water quality multiprobe (Manta 2, Eureka Water Probes, USA). An automatic water sampler (6712, Teledyne Isco, USA) collected water samples from the river every $48 \mathrm{~h}$ from June 2013 to June 2014 for analysis of water chemistry, and samples were collected fortnightly. Therefore, field and laboratory tests were undertaken to ensure that sample degradation over this time period was negligible. Furthermore, Milli-Q water was decanted into sample bottles in the field to create field blanks to ensure that no sample contamination occurred during transportation between the field and laboratory. Three riparian piezometers (screen depth installed in the soil C horizon, typically circa $2 \mathrm{~m}$ depth) with porewater sampling tubes at screen depth were installed in the banks at each site in summer 2013 to enable measure- ments of riparian hydraulic head and porewater samples to be collected for chemical analysis. Hydraulic head was measured using pressure transducers (HOBO U20-001-01, Onset Corporation, USA, at AS, GA and GN; Levelogger Edge, Solinst, Canada, at CE) validated with manual dips on a fortnightly basis. Porewater samples were collected from sampling tubes on the riparian piezometers every 2 months from February 2014 to June 2016 using a syringe and Tygon tubing. Samples were then filtered to $0.45 \mu \mathrm{m}$ in the field.

Sites AP and CW were a component of the Demonstration Test Catchment network (McGonigle et al., 2014; Outram et al., 2014). At AP, stream discharge was measured using a Mace Flow Pro to record paired stage height and velocity measurements at $15 \mathrm{~min}$ temporal resolution to which the velocity-area method was applied (Lloyd et al., 2016a, b). The Mace Flow Pro measurements were taken within a concrete section which meant that the cross-sectional area was stable. However, during high-flow events, the stage height overtops the concrete structure and out-of-bank flows occur. In these cases, a weir equation was implemented to account for the additional water flowing over the concrete section:

$Q_{i}=C_{\mathrm{d}} b H_{i}^{1: 5}$,

where $Q_{i}$ is the discharge at time point ${ }_{i}\left(\mathrm{~m}^{3} \mathrm{~s}^{-1}\right), C_{\mathrm{d}}$ is the dimensionless coefficient of discharge, $b$ is the weir crest breadth (m), and $H_{i}$ is the stage height (m) above the bridge at time point ${ }_{i} . C_{\mathrm{d}}$ was set at 2.7 based on typical values from published literature (Brater and King, 1976). Discharge data for $\mathrm{CW}$ were obtained from the Environment Agency Gauging Station (gauge number 43806 ), which provided $15 \mathrm{~min}$ resolution stage height data using a Thistle $24 \mathrm{R}$ incremental shaft encoder with a float and counterweight. For periods of modular flow, these data were used in conjunction with a stage-discharge curve to calculate discharge (ISO 11002 , 2010). However, during non-modular flow periods, the 
stage heights are used alongside 15 min velocity measurements from a second ultrasonic gauge to calculate discharge using the velocity-area method (ISO 1088, 2007). At both sites daily river water samples were collected using automatic water samplers (Teledyne Isco 3700, USA) and collected weekly.

\subsection{Laboratory analysis}

On return to the laboratory a sub-sample of river water from sites AS, GA, GN, and CE was filtered at $0.45 \mu \mathrm{m}$ for analysis of nitrate and DOC. Nitrate concentrations were analysed using ion exchange chromatography (DionexICS2500). The limits of detection (LOD) and precision were $8 \mu \mathrm{mol} \mathrm{L} \mathrm{L}^{-1} \pm 7 \%$. These samples were then prepared for DOC analysis by acidification to $\mathrm{pH}<2$ with $\mathrm{HCl}$ and then analysis by thermal oxidation (Skalar) using the nonpurgeable organic carbon (NPOC) method. The LOD of the DOC analysis was $42 \mu \mathrm{mol} \mathrm{L}{ }^{-1}$ with precision of $\pm 12 \%$. Accuracy was ensured by analysis of certified reference material (SPS-SW2 and TOIC4M14F1 for nitrate and DOC respectively) with each instrument run. Porewater samples from all sites were analysed using the same methods as for the surface water from AS, GA, GN, and CE.

River samples collected from sites AP and CW were filtered then analysed for nitrate using a Skalar San++ multichannel continuous flow autoanalyser. This analysis was based on the hydrazine-copper reduction method producing an azo dye measured colorimetrically at $540 \mathrm{~nm}$. DOC was analysed as non-purgeable organic carbon by coupled hightemperature catalytic oxidation using a Shimadzu TOC-L series analyser. For further details on sample collection and analysis at AP and CW sites see Yates et al. (2016).

\subsection{Data analysis}

BFI (BFI) for each site was calculated using the hydrograph separation procedure outlined in Gustard et al. (1992). Hydrographs with high BFI show relatively smooth characteristics and are indicative of major aquifers where water (and consequently solute) residence time in permeable bedrock will be of the order of decades, whereas a low BFI is characterized by a flashy hydrograph, with steep recession curves, and is indicative of a generally shorter residence time in the catchment before water reaches the stream channel, with quickflow comprising shallow, lateral preferential and overland pathways predominant during storm events. Soil moisture deficit (SMD) is defined as the amount of water (in mm) which would have to be added to the soil in order to bring it back to field capacity. SMD values were obtained from the UK Meteorological Office for MORECS square 169 (4000 east, 1400 north) for a medium textured soil type with predominantly grass cover.

In order to quantify the relationships between nitrate, DOC, and DOC: nitrate molar ratio with BFI, and to un- derstand how any relationship varied intra-annually, a linear mixed-effects modelling approach was used. Linear mixedeffects models account for missing data, which is a common issue associated with long-term field datasets, and the inclusion of repeated measures in the analysis (Blackwell et al., 2006). The "Imer" function in R (R Core Team, 2016) package lme4 (Bates et al., 2015) was used to perform a linear mixed-effects analysis of the relationship between BFI as the independent measure, and either nitrate concentration, DOC concentration, or DOC : nitrate molar ratios as the dependent variable. The nitrate and DOC concentration of river water recorded at each site over the same time period (i.e. from samples collected at simultaneous $48 \mathrm{~h}$ time intervals from June 2013 until June 2014) was used in the analysis. BFI was entered as a fixed effect. We accounted for the influence of repeated measures by including time (Julian day) as a random intercept and slope in the model. The "lme" function in R package "nlme" (Pinheiro et al., 2016) was used to fit a linear mixed effects model to porewater data to investigate differences in nitrate and DOC concentrations between CE and $\mathrm{CW}$ (the Chalk sites) and all the other sites (AS, AP, $\mathrm{GA}$, and GN).

For the purposes of considering the relationship between BFI and nitrate concentrations in the wider Hampshire Avon catchment, nitrate concentrations in river water samples collected between June 2013 and June 2014 were obtained from the Environment Agency Harmonised Monitoring Scheme (HMS) records. Average annual nitrate concentration was calculated for each site, but those with less than 12 samples in the 12-month period were removed from the analysis (number of samples ranged from 12 to 56 depending on the site). BFI for each Environment Agency site was estimated using the Flood Estimation Handbook, which uses the Hydrology of Soil Types (Boorman et al., 1995) methodology because there is not a gauging station at every location. Baseflow indices derived in this manner are referred to as BFIHOST to distinguish them from BFI values derived using our own discharge data. Pearson correlation analysis was used to explore relationships between solutes (nitrate and DOC) and BFI.

Annual loads of nitrate and DOC for sites AS, GA, and $\mathrm{CE}$ were calculated as kilograms per hectare by integrating paired concentration and discharge data collected on a $48 \mathrm{~h}$ basis from June 2013 to June 2014. Any missing solute data (maximum gap of 10 days due to equipment failure) were infilled using seasonal concentration-discharge relationships derived for each site. Seasonal loads are expressed as a percentage of total annual load for each site. 
(a)

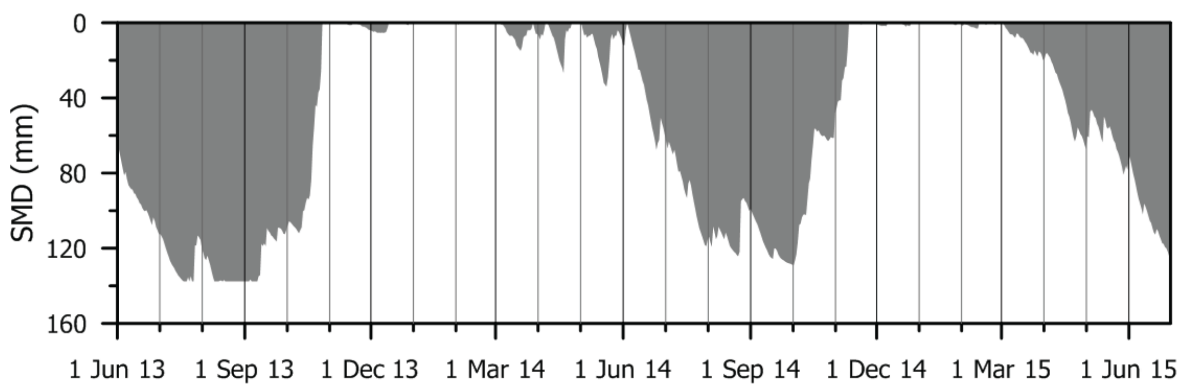

(b)

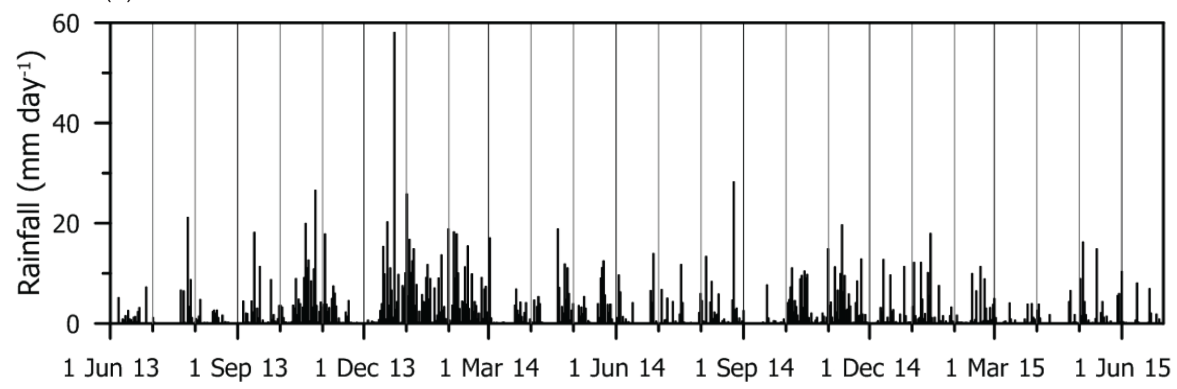

Figure 2. Soil moisture deficit (mm) and daily rainfall totals (mm) from June 2013 to June 2015.

\section{Results}

\subsection{Rainfall and soil moisture deficit during the study period}

The first year of study (June 2013-2014), on which these results are focused, was characterized by pronounced cycles of soil wetting and drying due to alternating periods of unusually wet and dry weather (Fig. 2). Due to a combination of lower-than-average rainfall (ca. 50\% of 1910-2015 longterm average for the region) and high temperatures $\left(>28^{\circ} \mathrm{C}\right.$ for a 10-12 day period in July) over the summer of 2013, SMD reached a maximum of $140 \mathrm{~mm}$ for a 4-week period in August and September 2013. A period of unsettled weather in October and November 2013 (224 mm rainfall in total) reduced the SMD to $0 \mathrm{~mm}$. After a brief return to dry, settled conditions, a series of deep Atlantic low-pressure systems brought a prolonged period of heavy rain to the entire Hampshire Avon catchment. A total of $161 \mathrm{~mm}$ rain fell in December 2013 (190\% of the 1961-1990 long-term average), with a maximum daily rainfall total of $58 \mathrm{~mm}$ on 23 December, followed by a further monthly total of 205 and $148 \mathrm{~mm}$ in January and February 2014, 261 and 259\% of the long-term averages, respectively. January 2014, in particular, was the equal wettest on record since 1910. SMD and rainfall patterns in 2014 were not as extreme as those in 2013, returning to monthly values that were much closer to the long-term averages. SMD reached peak values of $129 \mathrm{~mm}$ by the end of the summer in early October 2014, and autumn rainfall during October and November caused wetting-up of the soil to reduce SMD to $0 \mathrm{~mm}$ by mid-November 2014 . By March 2015, warmer weather, combined with lowerthan-average rainfall ( $<50 \%$ of long-term average), caused SMD to steadily increase until the end of the study period in June 2015.

\subsection{Quantification of the relationship between BFI and nutrients}

Nitrate concentration in surface water of our sub-catchments is significantly positively correlated with BFI $(r=0.749$, $p<0.001$ ), whereas DOC concentration in our surface water samples exhibits a significant negative correlation with BFI $(r=-0.881, p<0.001)$ (Fig. 3a, b, Table 2). The linear mixed effects model analysis indicates that BFI has a significant effect on nitrate $\left(\chi^{2}(1)=19, p<0.0001\right)$ and DOC $\left(\chi^{2}(1)=497, p<0.0001\right)$ concentrations, with an increase in BFI of 0.5 leading to a difference in average increase in surface water nitrate concentrations of $260 \mu \mathrm{mol} \mathrm{L}^{-1}$ and a reduction in DOC concentrations of $840 \mu \mathrm{mol} \mathrm{L}^{-1}$ between the clay and Chalk sites. Inclusion of time as a random effect (both slope and intercept) improved the model fit for both nitrate and DOC, indicating that temporal dynamics associated with these determinands are important to consider. The sites of lower BFI exhibit marked variations in nitrate concentration in autumn and winter, which change the slope (although not the overall direction) of the nitrate and BFI relationship, and highlight the importance of seasonality. Overall, the respective increase in nitrate, and decrease in DOC concentration with BFI, broadly reflects the patterns in concentrations 
(a)

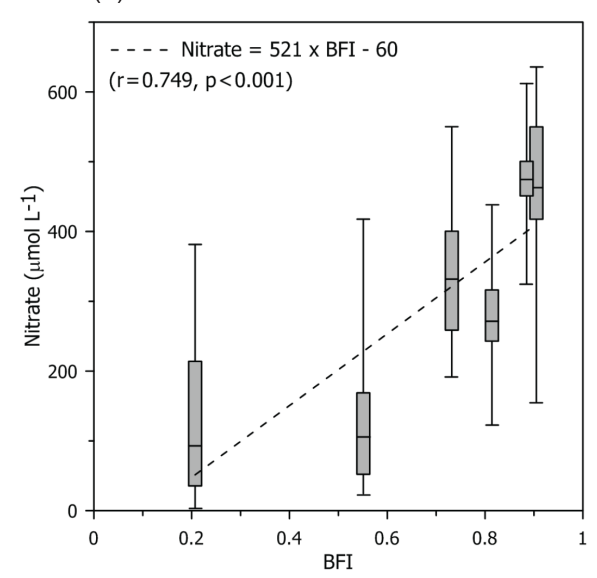

(c)

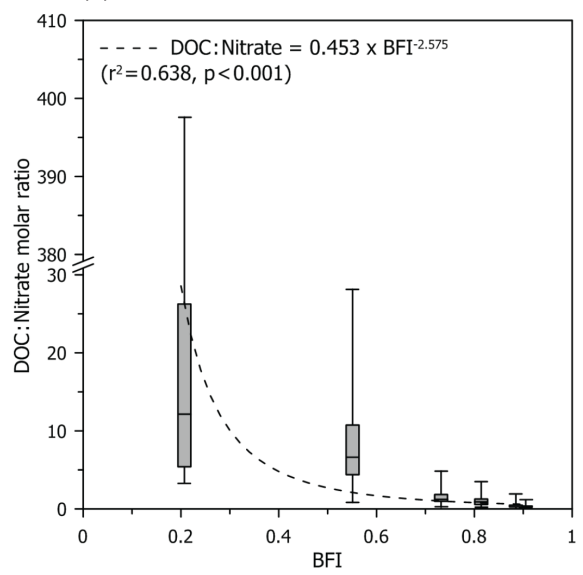

(b)

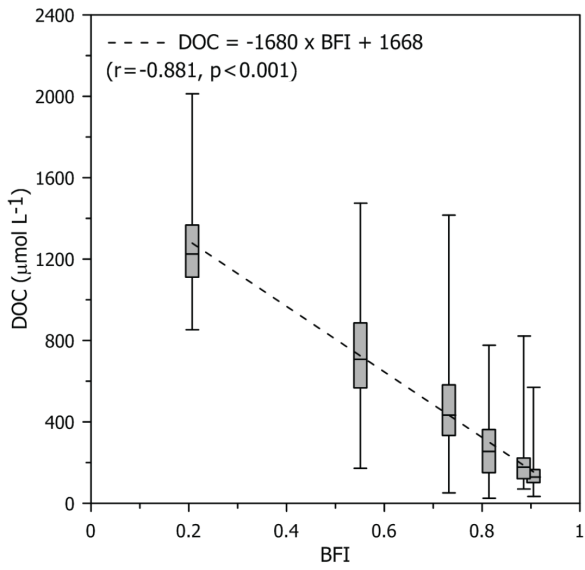

Figure 3. Relationship between (a) nitrate concentration and BFI, (b) DOC concentration and BFI, and (c) DOC : nitrate molar ratio and BFI for six sub-catchments in the Hampshire Avon.

of DOC and nitrate in the riparian zones associated with each geology. Nitrate concentrations in riparian porewaters were significantly higher in the Chalk sites compared to the clay and Greensand sites $\left(F_{(1,146)}=105, p<0.0001\right)$, whereas DOC concentrations were significantly lower in the Chalk sites compared to the others $\left(F_{(1,146)}=38, p<0.0001\right)$. The relationship between DOC : nitrate molar ratio and BFI is non-linear and can be best described by a power function $\left((\right.$ DOC $:$ nitrate $)=0.453 \times \mathrm{BFI}^{-2.575}, r^{2}=0.638, p<$ 0.001 , Fig. 3c).

The relationship between nitrate and BFIHOST was tested for 17 additional sites within the Hampshire Avon catchment using Environment Agency Harmonised Monitoring Scheme data collected between June 2013 and June 2014. Figure 4a shows that across the Hampshire Avon, there is a significant, positive, linear relationship between nitrate and BFIHOST $(r=0.951)$ with a regression model indicating that BFIHOST accounts for $90.4 \%$ of the variation in nitrate concentration. There is also a significant, positive correlation between nitrate concentration and \% arable land use $(r=0.839, p<0.001)$. Although $\%$ arable and BFIHOST are positively correlated $(r=0.881)$, a tolerance value (a test for collinearity) of 0.224 indicates that multiple linear regression can be used in this instance (Field, 2000). Multiple regression shows, however, that BFIHOST alone produces the best model, with the forced inclusion of $\%$ arable resulting in no significant improvement to the model fit (Table 2).

\subsection{Intra-annual variations of groundwater and quickflow contribution}

From this point forward, data from three sites only are presented as illustrative of the hydrochemical signatures from a range of BFIs across our three geologies; Chalk (site CE, high BFI), Greensand (site GA, intermediate BFI), and clay (site AS, low BFI). There is a marked difference in the response of electrical conductivity to discharge across the three sites (Fig. 5a-c). At the Chalk site, CE, a maximum electrical conductivity of $0.570 \mathrm{mS} \mathrm{cm}^{-1}$ is maintained across the full range of recorded discharge. At the Greensand site, GA, electrical conductivity is maintained at ca. $0.650 \mathrm{mS} \mathrm{cm}^{-1}$ until 
Table 2. Summary of (a) linear mixed-effects model parameters and (b) regression statistics.

\begin{tabular}{|c|c|c|c|c|c|}
\hline \multirow{2}{*}{\multicolumn{2}{|c|}{$\begin{array}{l}\text { (a) Model } \\
\text { Response variable }\end{array}$}} & \multicolumn{3}{|c|}{ Nitrate or DOC $\sim \mathrm{BFI}+(1+\mathrm{BFI} \mid$ Time $)$} & \\
\hline & & & & \\
\hline \multirow{2}{*}{\multicolumn{2}{|c|}{$\begin{array}{l}\text { AIC } \\
\text { Fitting method }\end{array}$}} & 10752.7 & \multicolumn{2}{|l|}{10576.2} & \\
\hline & & $\mathrm{ML}$ & \multicolumn{2}{|l|}{$\mathrm{ML}$} & \\
\hline \multicolumn{6}{|c|}{ Random effects } \\
\hline \multicolumn{2}{|c|}{ Intercept (time) } & 7117 & \multicolumn{2}{|l|}{89601} & \\
\hline \multicolumn{2}{|c|}{ BFI } & 10341 & \multicolumn{2}{|l|}{70703} & \\
\hline \multicolumn{2}{|c|}{ Residual } & 11558 & \multicolumn{2}{|l|}{19051} & \\
\hline \multicolumn{6}{|c|}{ Fixed effects } \\
\hline \multirow{2}{*}{\multicolumn{2}{|c|}{$\begin{array}{l}\text { Intercept } \\
\text { Slope }\end{array}$}} & \multirow{2}{*}{$\begin{array}{l}-59.98 \\
520.62( \pm 17.96)\end{array}$} & \multirow{2}{*}{\multicolumn{2}{|c|}{$\begin{array}{l}1668.2 \\
-1679.55( \pm 30.58)\end{array}$}} & \\
\hline & & & & & \\
\hline \multirow[t]{3}{*}{ iden } & Independent & $\begin{array}{r}\text { Correlation } \\
\text { coefficient }\end{array}$ & $\begin{array}{l}\text { Coefficient of } \\
\text { determination }\end{array}$ & $\begin{array}{r}\text { Slope } \\
(\mathrm{SE})\end{array}$ & Intercept \\
\hline & BFIHOST & 0.928 & $0.861^{*}$ & $535(47)$ & -45 \\
\hline & $\%$ arable & 0.839 & $0.704^{*}$ & $640(70)$ & 130 \\
\hline
\end{tabular}

$* p<0.0001$

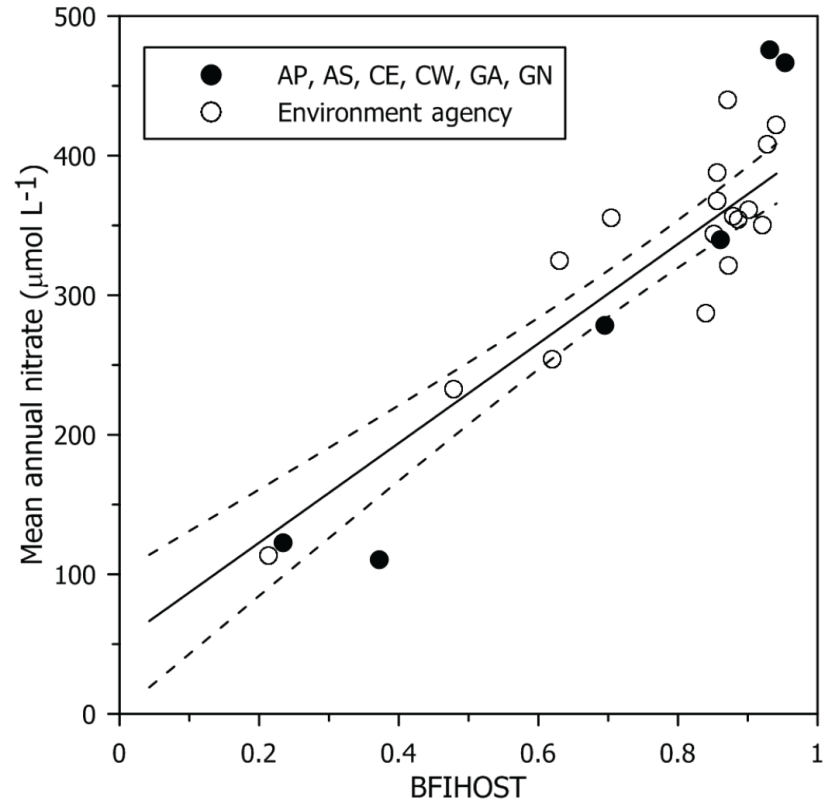

Figure 4. Relationship between nitrate concentration and BFI for this study and Environment Agency Harmonised Monitoring Scheme sites upstream of Salisbury in the Hampshire Avon (June 2013-2014).

discharge exceeds $1 \mathrm{~mm} \mathrm{~d}^{-1}$ and then a decline in electrical conductivity with increasing discharge is observed. An examination of electrical conductivity by season indicates that geogenic solute concentration was lowest at the Greensand site during winter 2014, and concentrations were comparable in spring, summer, and autumn (Fig. 5b). At the clay site, AS, there are two different relationships between electrical conductivity and discharge; a constant electrical conductivity of ca. $0.520 \mathrm{mS} \mathrm{cm}^{-1}$ is maintained at lower discharges of $0.001-0.3 \mathrm{~mm} \mathrm{~d}^{-1}$, whilst a log-linear decrease in electrical conductivity is observed between 0.2 and $3.5 \mathrm{~mm} \mathrm{~d}^{-1}$, and there is some overlap between the two patterns of behaviour. Box plots of electrical conductivity by season indicate highest concentrations of geogenic solutes in summer, intermediate concentrations in autumn and spring, and lowest concentrations in winter (Fig. 5c).

Inter-site comparisons of the response of nitrate, DOC, and DOC : nitrate molar ratio to variations in discharge are illustrated in Fig. 6. There is a significant, positive correlation between log-nitrate and log-discharge for all sites, with the slope of the regression relationship increasing with BFI $(\mathrm{CE}<\mathrm{GA}<\mathrm{AS}$; Table 3$)$. Visual examination of the relationship between nitrate and discharge for AS and GA suggests more than one trend is apparent and this is investigated in detail by considering seasonality below. There is also a significant, positive correlation between $\log$-DOC and $\log$ discharge, although in this case the slope of the regression relationship increases in the following order: $\mathrm{AS}<\mathrm{CE}<\mathrm{GA}$ (Table 3). However, again there is marked scatter in the relationship and this is investigated further below. There is a similar significant, proportional increase in DOC: nitrate molar ratio with increasing discharge at both $\mathrm{CE}$ and GA (slopes of 0.199 and 0.196 , respectively, on a $\log -\log$ basis, Table 3), 
(a)

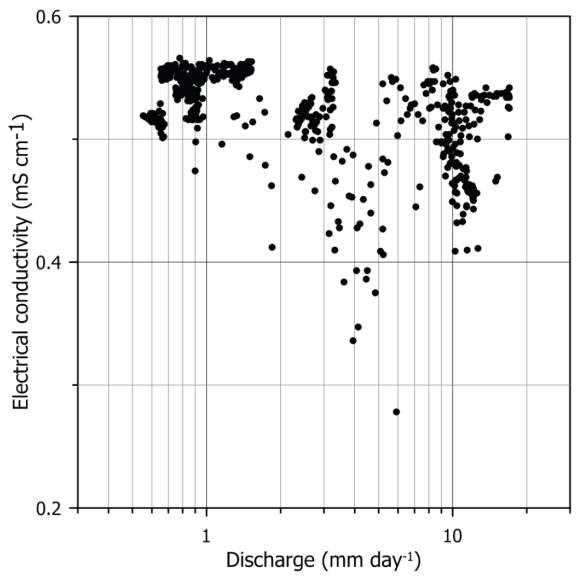

(c)

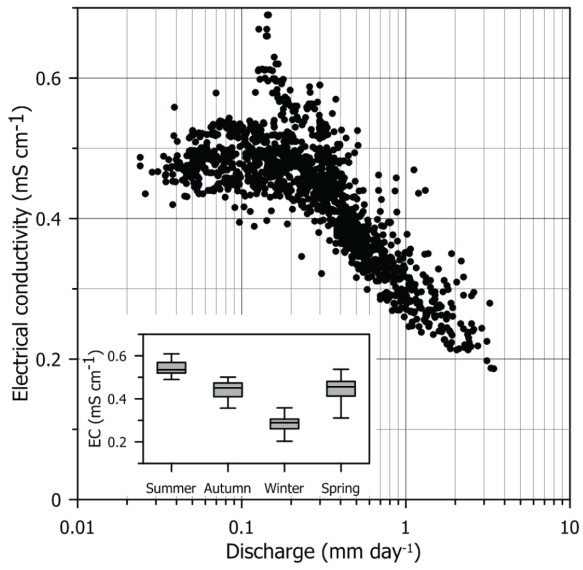

(b)

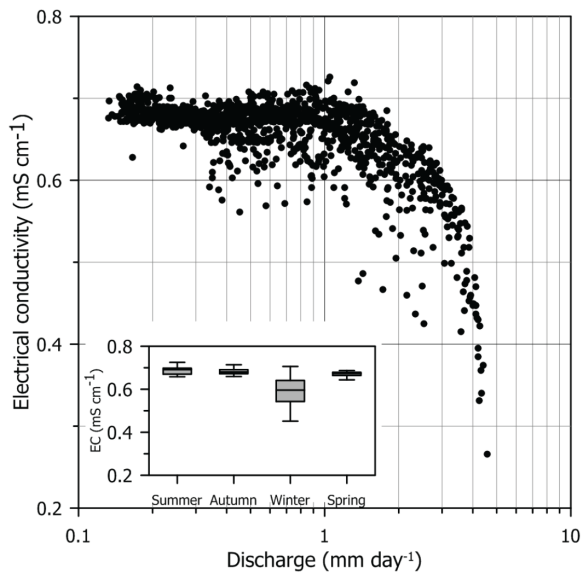

(d)

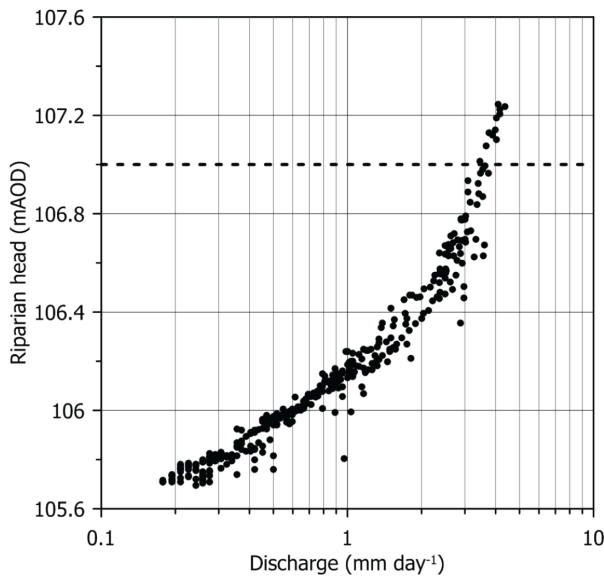

Figure 5. Relationship between electrical conductivity and discharge for three sub-catchments of contrasting geology in the Hampshire Avon (a) Chalk, CE; (b) Greensand, GA; and (c) clay, AS (June 2013-2015). Inset box-whisker plots illustrate seasonal variations in electrical conductivity for Greensand (b) and clay (c) sites. (d) Riparian head (mAOD) in relation to river discharge at site GA.

whilst AS has a much weaker relationship, exhibiting far greater scatter.

\subsection{Seasonality of concentration-discharge relationships for three selected sites}

Nitrate concentrations at the Chalk site, CE, show little variation with season or discharge, whereas DOC concentrations appear to follow two trends: (i) a slight increase in DOC concentration with discharge in spring and winter and (ii) elevated concentrations of DOC which are unrelated to discharge in spring (Fig. 7a). Consequently, DOC : nitrate molar ratios remain low $(<1)$ throughout the year (Table 4$)$.

At the Greensand site, GA, both nitrate and DOC concentrations increase with discharge (irrespective of season) until a breakpoint is observed at $1.5 \mathrm{~mm} \mathrm{~d}^{-1}$. At this point, during the winter storms of 2013-2014, nitrate concentrations start to decline with increasing discharge, whereas DOC concentrations drop to $<500 \mu \mathrm{mol} \mathrm{L} \mathrm{L}^{-1}$ and a new, positive trend in
Table 3. A summary of regression statistics for the relationships between log-nitrate, log-DOC and log-nitrate : DOC molar ratio by site with log-discharge.

\begin{tabular}{llllr}
\hline Site & Dependent & $R$ & $R^{2}$ & B (SE) \\
\hline CE & Log(nitrate) & 0.263 & $0.069^{* *}$ & $0.053(0.014)^{* *}$ \\
& Log(DOC) & 0.466 & $0.217^{* *}$ & $0.254(0.036)^{* *}$ \\
& Log-(DOC : nitrate) & 0.375 & $0.140^{* *}$ & $0.199(0.037)^{* *}$ \\
\hline GA & Log(nitrate) & 0.742 & $0.550^{* *}$ & $0.206(0.014)^{* *}$ \\
& Log(DOC) & 0.606 & $0.368^{* *}$ & $0.403(0.041)^{* *}$ \\
& Log-(DOC: nitrate) & 0.342 & 0.117 & $0.196(0.042)^{* *}$ \\
\hline AS & Log(nitrate) & 0.501 & $0.251^{* *}$ & $0.361(0.047)^{* *}$ \\
& Log(DOC) & 0.542 & $0.294^{* *}$ & $0.245(0.029)^{* *}$ \\
& Log-(DOC: nitrate) & 0.176 & $0.031^{*}$ & $-0.110(0.047)^{*}$ \\
\hline
\end{tabular}

${ }^{*} p<0.05 ;{ }^{* *} p<0.0001$. 
(a)

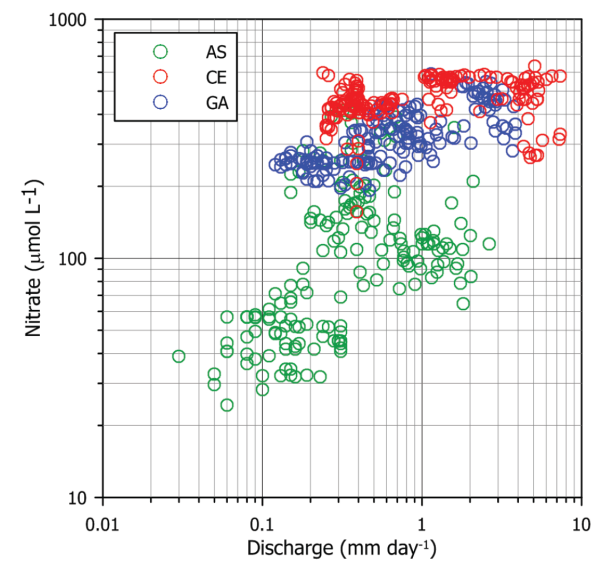

(c)

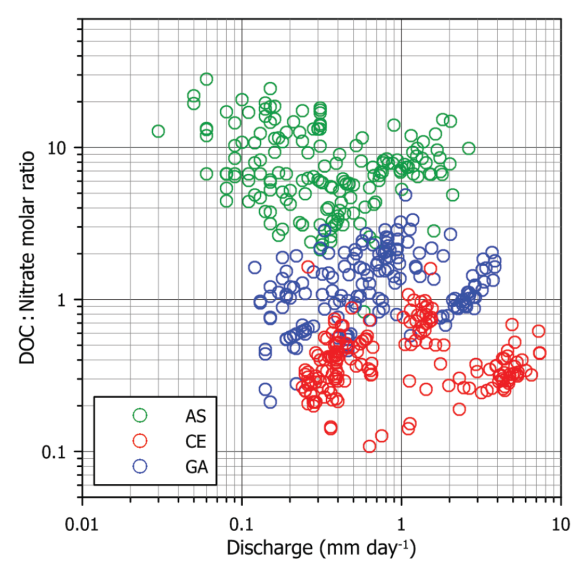

(b)

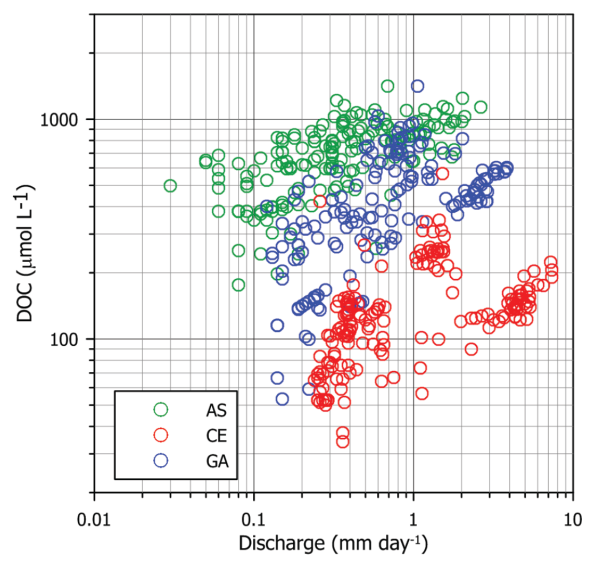

Figure 6. Inter-site comparison of the relationship between (a) nitrate concentration and discharge, (b) DOC and discharge, and (c) DOC : nitrate molar ratio and discharge for three sub-catchments of contrasting geology in the Hampshire Avon: Chalk, CE; Greensand, GA; and Clay, AS (June 2013-2014).

increasing DOC with increased discharge is observed with a gentler slope (Fig. 7b). As a consequence, the positive relationship between DOC: nitrate ratios and discharge also show a similar breakpoint, but the DOC : nitrate ratio remains below $3: 1$ throughout the year (Table 4).

At the clay site, AS, there are two trends in the concentration-discharge relationship for nitrate (Fig. 7c). Concentrations are highest $\left(200-400 \mu \mathrm{mol} \mathrm{L}^{-1}\right)$ during the autumn storms of intermediate discharge that followed the summer drought of 2013. The winter storms of 2014 are associated with highest discharge, but lower nitrate concentrations (ca. $100 \mu \mathrm{mol} \mathrm{L}^{-1}$ ). This contrasts with DOC which shows a plateau in concentration (ca. $1000 \mu \mathrm{mol} \mathrm{L}^{-1}$ ) with increasing discharge, irrespective of season. Nitrate and DOC concentrations were plotted against electrical conductivity to test whether nitrate and DOC arose from a linear combination of old (long residence time) and new (short residence time) water, but this was not the case (data not shown) suggesting that variations in supply and/or in-stream pro- cessing of these solutes occur through the seasons. At AS, there are two observable trends in DOC: nitrate molar ratio: (i) highest and the greatest variability in DOC: nitrate ratios is observed during summer low-flow conditions, and (ii) there is an increase in DOC: nitrate ratios with discharge irrespective of season (Fig. 7d). Consequently, during autumn, values of DOC : nitrate ratios were generally equal to or less than 5 , whilst values significantly greater than the threshold of 4 observed by Taylor and Townsend (2010) predominated during spring, summer, and winter (Table 4).

Over $50 \%$ of the annual DOC load was exported from our sub-catchments during winter months, irrespective of geology. In the spring, $22-28 \%$ of the annual DOC load was transported, with summer and autumn months together responsible for $<20 \%$ of the total weight of DOC leaving each sub-catchment (Table 4). Winter was also an important season for nitrate export with between 45 and $66 \%$ of the total annual nitrate load being exported. Spring export of nitrate was important in both Chalk and clay sub-catchments 
(a)

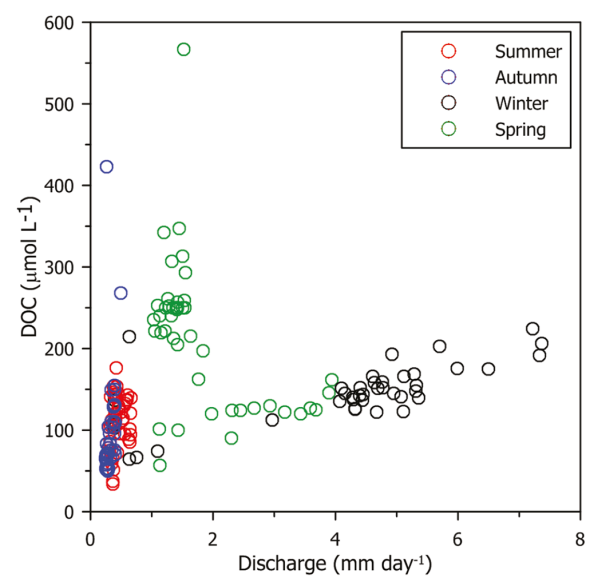

(c)

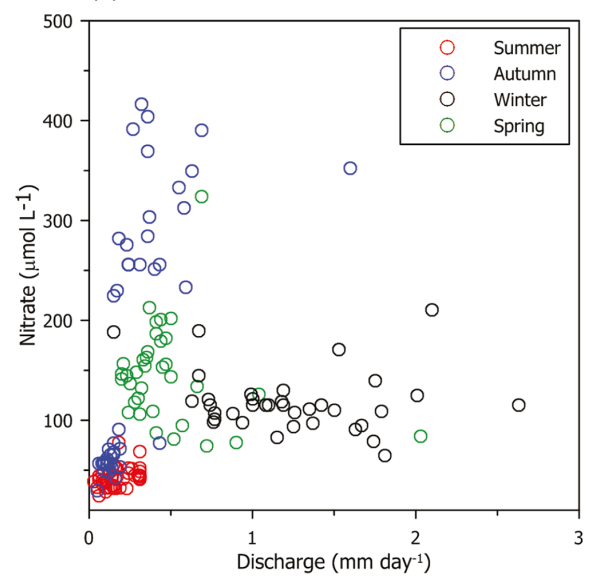

(b)

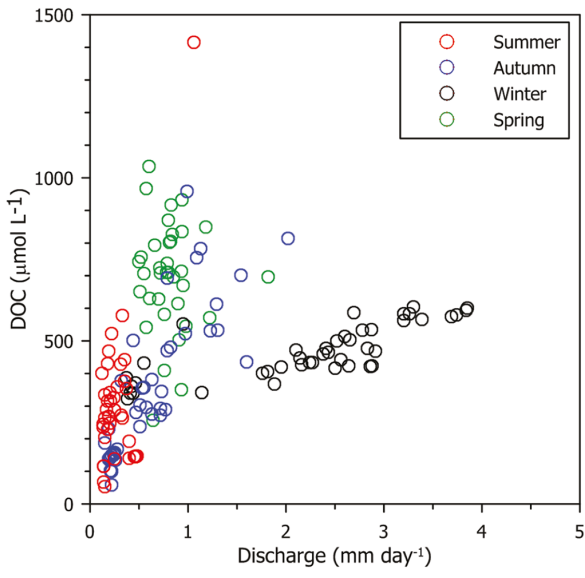

(d)

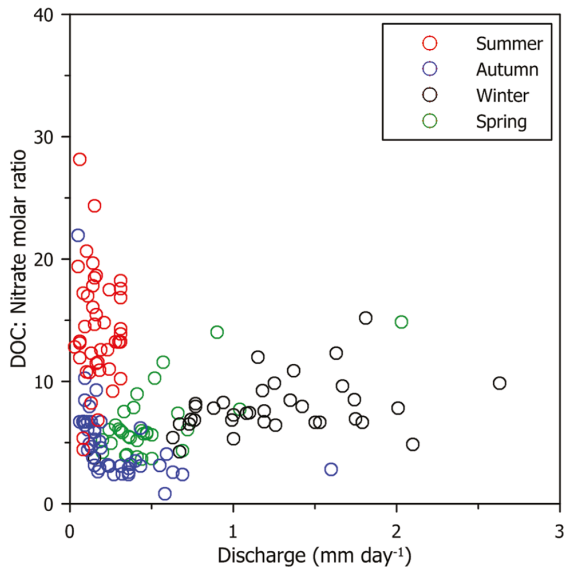

Figure 7. Seasonal variations in the relationship between nitrate, DOC and DOC : nitrate molar ratio with discharge for three sub-catchments of contrasting geology in the Hampshire Avon (June 2013-2014). (a) Chalk - CE; (b) Greensand - GA; (c) Clay - AS.

(ca. $30 \%$ of annual load) and in the clay, autumn export of nitrate was also of comparable magnitude to spring (Table 4).

\section{Discussion}

\subsection{Contrasting hydrological responses across a gradient of BFI}

Our six sites exhibit a range of BFI (0.207-0.905) indicating a gradient from river water with $80-90 \%$ groundwater contribution to total flow in the chalk geology, 70-80\% groundwater contribution in the Greensand, and only 20$55 \%$ groundwater characteristic at the sites underlain by clay geology. Our calculation of BFI for the six sites, based on our 2-year discharge dataset, compared favourably with the BFI estimated from HOST (Gustard et al., 1992).

BFI and $\operatorname{logEC}-\log Q$ plots are useful complementary approaches to interpreting hydrological and hydrochemical pathways operating in the sub-catchment associated with each site. Electrical conductivity is an aggregated measure of geogenic solute response in the sub-catchment, and provides an indication of relative contributions of old groundwater (long residence time) and new (short residence time) water arising from routes such as shallow throughflow, preferential pathways and overland flow to the river. The study allowed the full range of flows at the sites to be sampled because two extreme conditions in the UK were captured: the summer drought of 2013 and the extremely wet winter of 20132014. In the Chalk, the $\log \mathrm{EC}-\log Q$ plots show groundwater (old water) dominance during the period of flooding, because electrical conductivity is maintained through the entire range of flows, including at the highest discharge approaching $10 \mathrm{~mm} \mathrm{~d}^{-1}$. At the Greensand site, the sharp decline in electrical conductivity at discharges $>1.5 \mathrm{~mm} \mathrm{~d}^{-1}$ provides evidence of dilution of total dissolved solutes by new water, which occurs only during the wet winter of 2014. At the clay site, EC- $Q$ relationships demonstrate that quickflow pathways, most likely involving preferential delivery enabled by field drainage (both agricultural and army camp drains from 
Table 4. Export of nitrate and DOC expressed as \% of total annual load at each site, as well as mean DOC : nitrate ratio ( \pm SE) by season.

\begin{tabular}{|c|c|c|c|c|}
\hline & \multicolumn{4}{|c|}{ Season } \\
\hline & Summer & Autumn & Winter & Spring \\
\hline \multicolumn{5}{|c|}{ Nitrate seasonal load (as \% of annual) } \\
\hline AS & 3 & 26 & 45 & 26 \\
\hline GA & 5 & 12 & 66 & 16 \\
\hline $\mathrm{CE}$ & 6 & 4 & 57 & 31 \\
\hline \multicolumn{5}{|c|}{ DOC seasonal load (as \% of annual) } \\
\hline AS & 6 & 11 & 55 & 27 \\
\hline GA & 5 & 15 & 56 & 22 \\
\hline $\mathrm{CE}$ & 4 & 2 & 64 & 28 \\
\hline \multicolumn{5}{|c|}{ DOC : nitrate molar ratio } \\
\hline AS & $14.20(0.81)$ & $5.08(0.64)$ & $7.05(0.45)$ & $6.13(0.43)$ \\
\hline GA & $1.36(0.14)$ & $1.47(0.16)$ & $1.19(0.05)$ & $1.69(0.11)$ \\
\hline $\mathrm{CE}$ & $0.261(0.01)$ & $0.232(0.03)$ & $0.356(0.03)$ & $0.379(0.03)$ \\
\hline
\end{tabular}

World War II) installed due to the risk of seasonal waterlogging on the slowly permeable local clay soils (Denchworth and Wickham soil series), are operational throughout autumn, winter, and spring months. Under summer baseflow conditions, the field drains are inactive and any river flow (almost negligible during the summer drought of 2013) is provided by springs draining the aquifers of the Upper Greensand and Wardour Formation (Allen et al., 2014), or direct discharges from septic tanks, and drains connecting farm yards to the stream.

\subsection{Nitrate and DOC concentrations as a function of BFI}

Average annual nitrate concentrations in surface waters of the Hampshire Avon catchment increase with increasing BFI. In a UK-wide study, Davies and Neal (2007) used linear regression to consider how catchment characteristics control mean nitrate concentrations in UK rivers. Nitrate concentrations were explained by land use (\% arable and \% urban), topography (expressed as \% upland), effective rainfall (mm) and BFI. Therefore, on the basis of these prior national analyses, it would be predicted that $\%$ arable and BFI would be the most important explanatory factors. For the Hampshire Avon, stepwise regression analysis showed limited colinearity between BFI and \% arable, and forced entry regression indicated that BFI was the better explanatory variable for mean nitrate concentrations. In the UK, historical fertilizer applications have led to elevated concentrations of nitrate in both Chalk and Upper Greensand aquifers, currently in the range 500-645 $\mu \mathrm{mol} \mathrm{L}^{-1}$ (Department for Environment Food \& Rural Affairs, 2002; Burt et al., 2011; Howden et al., 2011; Wang et al., 2016). Although the Chalk aquifer of the Hampshire Avon has been designated as a groundwater nitrate vulnerable zone (NVZ) under the EU Nitrate Directive (Directive 2000/60/EC), the time taken for water to move from the soil surface, through the unsaturated zone to the aquifer can result in a decadal scale time-lag between implementation of management practice and any observed response in groundwater or river nitrate concentrations (Allen et al., 2014; Wang et al., 2012). We observe an increase in nitrate load in baseflow with increasing BFI (Chalk $>$ Greensand $>$ clay) in line with previous research by Tesoriero et al. (2013), and our riparian porewater samples indicate significantly higher nitrate concentrations in the soil $\mathrm{C}$ horizon of the Chalk sites in comparison to Greensand and clay sites. However, it is an over-simplification to suggest that the gradient of annual average nitrate concentrations with BFI can be explained solely by different ratios of nitrate-rich groundwater to relatively nitrate-poor quickflow components of the hydrograph over an annual cycle. If this were the case, then nitrate concentrations would be highly correlated with electrical conductivity, and they are not. Instead, our analysis suggests that additional $\mathrm{N}$ transformation processes, and exchange with other $\mathrm{N}$ species forms instream, driven by seasonality and varying land use and management contribute to the observed patterns that we see, and this is discussed below.

Our six sites provide evidence that average annual DOC concentrations decline with increasing BFI in the Hampshire Avon catchment. Unfortunately, the Environment Agency does not collect DOC data in the rivers of the Hampshire Avon region so we cannot investigate the wider applicability of the DOC trend. Wetland area is often cited as an important control on DOC concentrations in a catchment (Morel et al., 2009), but our sub-catchments all comprise $<0.6 \%$ wetlands by area. Data from the Environment Agency indicate that groundwater concentrations of DOC in the catchment are generally $<83 \mu \mathrm{mol} \mathrm{L}{ }^{-1}$. Porewater samples from the grassland riparian zone at each site show elevated DOC concentrations in comparison to regional groundwater, and the Chalk sites (high BFI) have significantly lower DOC concentrations in soil $\mathrm{C}$ horizons compared to the Greensand and clays, suggesting that soil type and underlying geology could influence the concentration at which DOC is delivered to the stream in these sub-catchments. Once again, DOC concentrations in the surface water cannot be explained by a mix of old and new water alone, and seasonality plays an important role in controlling the flux of DOC through river water.

\subsection{Seasonal controls on nitrate and DOC export}

The Chalk site (CE) is near-chemostatic with respect to total dissolved solutes and nitrate. This means that the absolute concentration of geogenic solutes and nitrate is maintained at higher discharge, so that discharge drives solute load and hence the export of solutes to the coast. Here we use the definition of near-chemostatic expressed in Godsey et al. (2009) 
as a slope of close to zero on a $\log (C)-\log (Q)$ plot, where $C$ is concentration and $Q$ is discharge. It has been suggested that chemostatic behaviour for nutrients arises if sources accumulate in the landscape, e.g. as legacy of nitrate management (Basu et al., 2010). Here nitrate has accumulated in groundwater (Wang et al., 2016) and it is the dominance of this old water under high discharge that gives rise to the nearchemostatic effect and transport-limited system. DOC is also transport rather than supply limited at this site, showing a slight increase in concentration with increasing discharge, and a more pronounced increase in spring which is not associated with a rise in discharge. In fact all three sites - on Chalk, Greensand, and clay - have elevated DOC concentrations in spring, which could arise from production, leaching and export of DOC from catchment soils as soil temperatures rise (Aubert et al., 2013), and/or in-stream production.

At the Greensand site, there appears to be a threshold of discharge of ca. $1.5 \mathrm{~mm} \mathrm{~d}^{-1}$ in winter above which there is evidence of different hydrological flowpath(s) or sources of water to the river with lower electrical conductivity compared to other seasons. Riparian head is closely correlated with discharge and shows two distinct regions of linearity which converge at a discharge of between 1 and $1.5 \mathrm{~mm} \mathrm{~d}^{-1}$. At this threshold, riparian head is at $60-80 \mathrm{~cm}$ below the ground surface suggesting that the water table is at the base of the soil $\mathrm{C}$ horizon. As the water rises up through the soil horizons during the winter, the electrical conductivity in the river water drops indicating a supply of new water from soil in the riparian zone and potentially from the surrounding fields. Conceptualizations of solute transport from other researchers include differing contributions from near stream riparian areas with rising and falling groundwater, arising from a combination of soil solute concentration and nearstream lateral water flux (Prior and Johnes, 2002; Seibert et al., 2009), and/or increased connectivity and fraction of active catchment contributing water, with emphasis on the lateral dimension (Basu et al., 2010). Above the threshold of $1.5 \mathrm{~mm} \mathrm{~d}^{-1}$ the DOC and nitrate concentrations in the river reflect a combination of groundwater contribution and the depth-integrated mass flux of each solute from the soil A, B, and $\mathrm{C}$ horizons. The reason for a decline in nitrate concentrations in river water above the threshold, whilst DOC concentrations increase, can be ascribed to the different depthdistributions of nitrate and DOC pools in the soil. The extent of the lateral connectivity between surrounding fields, the riparian zone, and the river channel in these low-gradient, intermediate BFI systems is not well characterized, and should be an area of further study.

Our two clay sub-catchments are dominated by artificially drained soils of the Kimmeridge Clay Series, and the field under-drainage will be a major control on the hydrological and hydrochemical response of the river. This is evident in the rapid fall in electrical conductivity in response to rainfall events (Fig. S1 in the Supplement) and in the variation in electrical conductivity with season which arises from the mix of rapid (via drainflow) and slow pathways of water during storm events, and suggests that the drains operate through much of the year (spring, autumn and winter). Concentrations of DOC in the surface waters of the two clay sites $\left(167-2000 \mu \mathrm{mol} \mathrm{L}^{-1}\right)$ are comparable to the range reported in drainage waters from permanent grassland in South West England (Sandford et al., 2013). Increases in DOC concentrations in drainage water during rainfall events have previously been explained as being due to increased lateral flows through the upper soil horizons (Neff and Asner, 2001), which are generally relatively carbon enriched compared to lower soil horizons. Here, flushing of DOC from soil aggregates and subsurface micropores contributes to rising concentrations during storm events (Jardine et al., 1990; Chittleborough et al., 1992). Sandford et al. (2013) reported molar DOC : nitrate ratios of 18-25 at times of highest DOC export in drainage water (which is at the upper end of our observations for surface water of our clay catchment), and they also found that the molar DOC: nitrate ratio increased with discharge. The comparability of results suggests that our findings may have wider applicability to other catchments of mineral soils dominated by drained grassland.

The elevated concentrations of nitrate observed in the river Sem in Autumn 2013 (Fig. S2) provide some additional evidence to support results from dynamic modelling using INCA-N which show that drought conditions followed by wetting-up of soil (as predicted in future climate change scenarios) can give rise to high nitrate loads in rivers (Whitehead et al., 2006). However, we observed this flushing effect most markedly in the clay sub-catchment of the Hampshire Avon where the majority of nitrate is likely to be delivered rapidly to the stream through shallow subsurface pathways connected to topsoil, as opposed to the Chalk sub-catchments where groundwater contributions of nitrate dominate.

\subsection{Ecological significance of temporal variations in DOC : nitrate ratio across a gradient of BFI}

Here, we have shown that for our six tributaries of the Hampshire Avon, DOC: nitrate ratios are negatively correlated with BFI, but the relationship is non-linear. As far as we are aware, we are the first to demonstrate such a relationship, which, if more widely applicable to other lowland, agricultural catchments, might provide a useful means of predicting annual-averaged riverine nitrate and DOC concentrations.

The molar DOC: nitrate ratios fall in the lowest range recorded across multiple land use types in the US LINXII study (Mulholland et al., 2015), but vary over 2 orders of magnitude, suggesting order of magnitude variations in whole-stream nitrate uptake velocity in river reaches across our contrasting geologies $\left(0.05-0.4 \mathrm{~mm} \mathrm{~min}^{-1}\right.$; see Fig. 7 in Rodríguez-Cardona et al., 2016). Nitrate uptake velocity is the vertical movement of nitrate to the riverbed measured using the whole-stream "Tracer Additions as Spiraling Curve Characterization" method. The metric represents nitrate up- 
take efficiency, and can be interpreted as whole-stream nitrate removal through, for example, denitrification and/or assimilatory processes, although the method does not allow for discrimination of these processes. On the basis of the relationship between DOC: nitrate and BFI demonstrated in this study, we can hypothesize that the clay sub-catchments are associated with higher whole-stream nitrate removal than our Greensand and Chalk systems. Although we have no direct measurements of whole-stream nitrate removal for these sites, we have measured in situ rates of nitrate removal in the riverbed at these six sites using a modified push-pull technique (Jin et al., 2016), and the highest rates of nitrate removal were found at the two clay sites (see Table 4 in Jin et al., 2016). Whether DOC : nitrate ratios control nitrate removal may also depend on the net heterotrophic or autotrophic nature of our sub-catchments. In a net autotrophic reach, nitrate removal might correlate with physical factors such as light and temperature, which control photosynthetic activity, and hence the in-stream production of labile carbon which, in turn, is then tightly coupled to nitrate reduction. In contrast, in a net heterotrophic reach in our lowland, arable landscape, nitrate removal may depend on DOC: nitrate ratios driven by hydrological pathways delivering labile dissolved organic and inorganic carbon (Rodriguez-Cardona et al., 2016).

This study, amongst others, has revealed significant differences in the relationship between DOC : nitrate and discharge dependent on both geology and seasonal effects (Tiemeyer and Kahle, 2014; Thomas et al., 2016). The Chalk site exhibited little variation in DOC: nitrate with discharge due to the dominance of groundwater contribution at both high and low flows. At the Greensand site, there is a linear increase in DOC : nitrate with discharge irrespective of season. However, during the elevated flows in the winter, when riparian and rain water contributes increasingly to the discharge, causing a drop in electrical conductivity, a sharp change in nitrate and DOC concentration is observed resulting in an overall drop in DOC: nitrate during a time when $>66 \%$ of the total nitrate export occurs. In contrast at the clay site, lowest DOC: nitrate values and highest nitrate concentrations are associated with autumn storms of intermediate discharge, which export $26 \%$ of total annual nitrate load. These trends highlight contrasting seasons of risk associated with high nitrate export in combination with low DOC: nitrate ratios at the Greensand and clay sites. Our research gives added impetus to the need to control autumn run-off from drained, grassland catchments supporting intensive livestock farming. Our study also suggests that during winter, periods of lateral flow and over-bank flooding in areas of intermediate BFI, such as Greensand, may export a significant proportion of the annual nitrate load with little opportunity for in-stream nitrate processing or removal.

\section{Conclusions}

We have shown that the dynamism of hydrological pathways, here quantified using BFI, is a controlling factor influencing both annual average DOC and nitrate concentrations in heavily managed agricultural landscapes.

- In the Chalk sub-catchment, a near-chemostatic nitrate response over the year is a consequence of the dominance of nitrate-rich groundwater flow, and nitrate export is transport controlled. Thus, under future climate change scenarios, periods of groundwater flooding such as observed in winter 2013-2014 will be critical periods of nitrate export with little opportunity for in-stream nitrate processing and removal due to a combination of short residence times, low water temperatures and low DOC : nitrate ratios $(<0.5)$.

- In sub-catchments of intermediate BFI, such as the Greensand sub-catchments in this study, high winter flows, although arising from a mix of slow and rapid hydrological pathways, may also be characterized by water with low DOC: nitrate ratios ca. 1, suggesting that nitrate accrual rather than in-stream nitrate removal could be promoted downstream.

- Although heavily managed, the clay sub-catchment showed marked variation in nitrate and DOC concentrations with discharge, driven by season. In this sub-catchment there was a strong positive relationship between DOC: nitrate ratio and discharge, and DOC concentrations were generally higher than for our other landscape types. It seems that, at the landscape scale, both quickflow and preferential flow through field drains may supply rivers with a source of water conducive to promoting in-stream nutrient removal. Although care should be taken to ensure that in such catchments, relatively high DOC concentrations do not arise from pollutant sources with a high biochemical oxygen demand (such as slurry), further work should focus on the sources and lability of DOC from drained, grassland soils.

At the landscape scale, it can be hypothesized that the locations where water from impermeable sub-catchments meet water from tributaries of lower BFI may be hotspots of heterotrophic activity driven by upstream supply of water with a high DOC : nitrate ratio. In this way, the spatial arrangement of areas of contrasting BFI within a catchment may have important ecological and biogeochemical consequences for receiving waters, especially if they are designated as NVZs, or transitional and near-coastal areas.

Data availability. Data are available to download from the NERC Environmental Information Data Centre (see links provided in Heppell et al., 2016a, b). DTC data are available under 
an Open Government Licence from https://data.gov.uk/dataset/ demonstration-test-catchments-data-archive.

\section{The Supplement related to this article is available online at https://doi.org/10.5194/hess-21-4785-2017- supplement.}

Competing interests. Author Jim E. Freer is a member of the editorial board of the journal.

Acknowledgements. This work was funded by the NERC Macronutrient Cycles thematic programme (grant numbers NE/J012106/1 and NE/J011738/1) and by the Demonstration Test Catchment phase 1 project (grant number WQ0211) co-funded by Defra, Environment Agency (EA) and the Welsh Assembly Government (WAG). C. M. Heppell and A. Binley would like to thank the team who helped to set up the Macronutrient Cycles sampling network and collected and processed the water samples reported in this study: John Keery and James Tempest. The DTC phase 1 sampling network was installed by Robin Hodgkinson and Jeff Short and serviced by Fiona Grant and Carla Richmond (all ADAS), while all laboratory analyses were completed by Geoff Warren, Moragh Stirling and Chris Yates at the University of Reading. Geoff Hardwicke of the Environment Agency, Blandford, kindly provided access to the discharge data for Brixton Deverill on the River Wylye. We are also very grateful to Natalie Ludgate and Angela Fells for analysing the water samples in our laboratories. Finally, this work would not have been possible without the kind and continual support of the landowners and tenant farmers at our six sites.

Edited by: Laurent Pfister

Reviewed by: two anonymous referees

\section{References}

Ågren, A., Buffam, I., Jansson, M., and Laudon, H.: Importance of seasonality and small streams for the landscape regulation of dissolved organic carbon export, J. Geophys. Res.-Biogeo., 112, G03003, https://doi.org/10.1029/2006jg000381, 2007.

Aitkenhead, J. A. and McDowell, W. H.: Soil $\mathrm{C}: \mathrm{N}$ ratio as a predictor of annual riverine DOC flux at local and global scales, Global Biogeochem. Cy., 14, 127-138, https://doi.org/10.1029/1999gb900083, 2000.

Allen, D. J., Darling, W. G., Davies, J., Newell, A. J., Gooddy, D. C., and Collins, A. L.: Groundwater conceptual models: implications for evaluating diffuse pollution mitigation measures, Q. J. Eng. Geol. Hydroge., 47, 65-80, https://doi.org/10.1144/qjegh2013043, 2014.

Aubert, A. H., Gascuel-Odoux, C., Gruau, G., Akkal, N., Faucheux, M., Fauvel, Y., Grimaldi, C., Hamon, Y., Jaffrézic, A., LecozBoutnik, M., Molénat, J., Petitjean, P., Ruiz, L., and Merot, P.: Solute transport dynamics in small, shallow groundwaterdominated agricultural catchments: insights from a highfrequency, multisolute $10 \mathrm{yr}$-long monitoring study, Hydrol.
Earth Syst. Sci., 17, 1379-1391, https://doi.org/10.5194/hess-171379-2013, 2013.

Basu, N. B., Destouni, G., Jawitz, J. W., Thompson, S. E., Loukinova, N. V., Darracq, A., Zanardo, S., Yaeger, M., Sivapalan, M., Rinaldo, A., and Rao, P. S. C.: Nutrient loads exported from managed catchments reveal emergent biogeochemical stationarity, Geophys. Res. Lett., 37, L23404, https://doi.org/10.1029/2010gl045168, 2010.

Basu, N. B., Thompson, S. E., and Rao, P. S. C.: Hydrologic and biogeochemical functioning of intensively managed catchments: A synthesis of top-down analyses, Water Resour. Res., 47, W00J15, https://doi.org/10.1029/2011wr010800, 2011.

Bates D., Maechler, M., Bolker, B., and Walker, S.: Fitting linear mixed-effects models using lme4, J. Stat. Softw., 67, 1-48, https://doi.org/10.18637/jss.v067.i01, 2015.

Battin, T. J., Luyssaert, S., Kaplan, L. A., Aufdenkampe, A. K., Richter, A., and Tranvik, L. J.: The boundless carbon cycle, Nat. Geosci., 2, 598-600, https://doi.org/10.1038/ngeo618, 2009.

Bernhardt, E. S. and Likens, G. E.: Dissolved Organic Carbon Enrichment Alters Nitrogen Dynamics in a Forest Stream, Ecology (Durham), 83, 1689-1700, 2002.

Beusen, A. H. W., Dekkers, A. L. M., Bouwman, A. F., Ludwig, W., and Harrison, J.: Estimation of Global River Transport of Sediments and Associated Particulate $\mathrm{C}, \mathrm{N}$ and $\mathrm{P}$, Global Biogeochem. Cy., 19, GB4S05, https://doi.org/10.1029/2005GB002453, 2005.

Billen, G., Silvestre, M., Grizzetti, B., Leip, A., Bouraoui, F., Behrendt, H., Garnier, J., Humborg, C., Smedberg, E., Johnes, P. J., Kaste, O., Curtis, C., Lepisto, A., Kortelainen, P., Ganeshram, R., Beusen, A., and Voss, M.: Nitrogen flux to coastal waters from regional European watersheds, Chapter 13 in: European Nitrogen Assessment, edited by: Sutton, M. A., Howard, C. M., Erisman, J. W., Billen, G., Bleeker, A., Grennfelt, P., van Grinsven, H., and Grizzetti, B., Cambridge University Press, 271-297, ISBN: 9781107006126, 2011.

Blackwell, E., Mendes de Leon, C. F., and Miller, G. E.: Applying mixed regression models to the analysis of repeated-measures data in psychosomatic medicine, Psychosom. Med., 68, 870878, 2006.

Boorman, D. B., Hollis, J. M., and Lilly, A.: Hydrology of Soil Types: A Hydrologically Based Classification of the Soils of the United Kingdom, Institute of Hydrology Report No. 126, 1995.

Brater, E. F. and King, H. W.: Handbook of hydraulics for the solution of hydraulic engineering problems, McGraw-Hill, New York, London, 1976.

Bristow, C. R., Barton, C. M., Westhead, R. K., Freshney, C. R., Cox, B. M., and Woods, M. A.: The Wincaton District: a concise account of the geology, Memoir for 1:50000 Geological Sheet 297, British Geological Survey, Keyworth, Nottingham, 1999.

Burt, T. P., Howden, N. J., Worrall, F., Whelan, M. J., and Bieroza, M.: Nitrate in United Kingdom rivers: policy and its outcomes since 1970, Environ. Sci. Technol., 45, 175-181, 2011.

Carpenter, S. R., Caraco, N. F., Correll, D. L., Howarth, R. W., Sharpley, A. N., and Smith, V. H.: Nonpoint pollution of surface waters with phosphorus and nitrogen, Ecol. Appl., 8, 559-568, 1998.

Chittleborough, D. J., Smettem, K. R. J., Cotsaris, E., and Leaney, F. W.: Seasonal changes in path-ways of dissolved organic carbon 
through a hillslope soil (xeralf) with contrasting texture, Aust. J. Soil Res., 30, 465-476, 1992.

Dagg, M., Benner, R., Lhrenz, S., and Lawrence, D.: Transformation of Dissolved and Particulate Materials on Continental Shelves Influenced by Large Rivers: Plume Processes, Cont. Shelf Res., 24, 833-858, 2004.

Davies, H. and Neal, C.: Estimating nutrient concentrations from catchment characteristics across the UK, Hydrol. Earth Syst. Sci., 11, 550-558, https://doi.org/10.5194/hess-11-550-2007, 2007.

Department for Environment Food \& Rural Affairs: a Diffuse Pollution Review, Defra, London, 2002.

Dodds, W. K., Marti, E., Tank, J. L., Pontius, J., and Hamilton, S. $\mathrm{K}$.: Carbon and nitrogen stoichiometry and nitrogen cycling rates in streams, Oecologia, 140, 458-467, 2004.

Durand, P., Breur, L., Johnes, P. J., van Grinsven, H., Butturini, A., Billen, G., Garnier, J., Maberley, S., Carvalho, L., Reay, D., and Curtis, C.: Nitrogen turnover processes and effects in aquatic ecosystems, Chapter 7, in: European Nitrogen Assessment, edited by: Sutton, M. A., Howard, C. M., Erisman, J. W., Billen, G., Bleeker, A., Grennfelt, P., van Grinsven, H., Grizzetti, B., Cambridge University Press, 126-146, ISBN: 9781107006126, 2011.

Field, A.: Discovering statistics using SPSS for Windows, Sage Publications Ltd., London, 2000.

Frost, P. C., Larson, J. H., Johnston, C. A., Young, K. C., Maurice, P. A., Lamberti, G. A., and Bridgham, S. D.: Landscape predictors of stream dissolved organic matter concentration and physicochemistry in a Lake Superior river watershed, Aquat. Sci., 68, 40-51, https://doi.org/10.1007/s00027-005-0802-5, 2006.

Galloway, J. N. and Cowling, E. B.: Reactive nitrogen and the world: 200 years of change, Ambio, 31, 64-71, 2002.

Godsey, S. E., Kirchner, J. W., and Clow, D. W.: Concentrationdischarge relationships reflect chemostatic characteristics of US catchments, Hydrol. Process., 23, 1844-1864, 2009.

Goodale, C. L., Aber, J. D., Vitousek, P. M., and McDowell, W. H.: Long-term decreases in stream nitrate: Successional causes unlikely; Possible links to DOC?, Ecosystems, 8, 334-337, https://doi.org/10.1007/s10021-003-0162-8, 2005.

Grebliunas, B. D. and Perry, W. L.: The role of $\mathrm{C}: \mathrm{N}: \mathrm{P}$ stoichiometry in affecting denitrification in sediments from agricultural surface and tile-water wetlands, SpringerPlus, 5, 359, https://doi.org/10.1186/s40064-016-1820-6, 2016.

Gustard, A., Bullock, A., and Dixon, J. M.: Low flow estimation in the United Kingdom, Institute of Hydrology, Report No. 108, Institute of Hydrology, 292 pp., 1992.

Heathwaite, A. L.: Multiple stressors on water availability at global to catchment scales: understanding human impact on nutrient cycles to protect water quality and water availability in the long term, Freshwater Biol., 55, 241-257, https://doi.org/10.1111/j.1365-2427.2009.02368.x, 2010.

Heppell, C. M. and Binley, A.: Hampshire Avon: Daily discharge, stage and water chemistry data from four tributaries (Sem, Nadder, West Avon, Ebble), NERC Environmental Information Data Centre, https://doi.org/10.5285/0dd10858-7b96-41f18db5-e7b4c4168af5, 2016a.

Heppell, C. M. and Binley, A.: Hampshire Avon: Vertical head gradient, saturated hydraulic conductivity and pore water chemistry data from six river reaches, NERC Environmental Information
Data Centre, https://doi.org/10.5285/d82a04ce-f04d-40b4-97501a2bf7dc29a3, 2016b.

Howden, N. J. K., Burt, T. P., Worrall, F., Mathias, S., and Whelan, M. J.: Nitrate pollution in intensively farmed regions: what are the prospects for sustaining highquality groundwater?, Water Resour. Res., 47, W00L02, https://doi.org/10.1029/2011WR010843, 2011.

Howarth, R. W., Swaney, D., Billen, G., Garnier, J., Hong, B., Humborg, C., Johnes, P. J., Morth, M., and Marino, R.: Nitrogen Fluxes from the Landscape are Controlled by Net Anthropogenic Nitrogen Inputs and by Climate, Front. Ecol. Environ., 10, 37 43, https://doi.org/10.1890/100178, 2012.

Jardine, P. M., Wilson, G. V., McCarthy, J. F., Luxmoore, R. J., Taylor, D. L., and Zelany, L. W.: Hydrogeochemical processes controlling the transport of dissolved organic carbon through a forested hill-slope, J. Environ. Contam. Hydrol., 6, 3-19, 1990.

Jin, L., Whitehead, P. G., Heppell, C. M., Lansdown, K., Purdie, D. A., and Trimmer, M.: Modelling flow and inorganic nitrogen dynamics on the Hampshire Avon: Linking upstream processes to downstream water quality, Sci. Total Environ., 572, 1496-1506, 2016.

Jiang, R., Woli, K. P., Kuramochi, K., Hayakawa, A., Shimizu, M., and Hatano, R.: Hydrological process controls on nitrogen export during storm events in an agricultural watershed, Soil Sci. Plant. Nutr., 56, 72-85, 2010.

International Organization for Standardization: ISO 1088, Hydrometry - Velocity-area Methods Using Current-Meters - Collection and Processing of Data for Determination of Uncertainties in Flow Measurement, ISO Standards, 2007.

International Organization for Standardization: ISO 1100-2, Hydrometry - Measurement of Liquid Flow in Open Channels Part 2: Determination of the Stage-discharge Relationship, ISO Standards, 2010.

Lloyd, C. E. M., Freer, J. E., Johnes, P. J., Coxon, G., and Collins, A. L.: Discharge and nutrient uncertainty: implications for nutrient flux estimation in small streams, Hydrol. Proc., 30, 135-152, 2016a.

Lloyd, C. E. M., Freer, J. E., Johnes, P. J., and Collins, A. L.: Using hysteresis analysis of high-resolution water quality monitoring data, including uncertainty, to infer controls on nutrient and sediment transfer in catchments, Sci. Total Environ., 543, 388-404, 2016b.

McGonigle, D. F., Burke, S. P., Collins, A. L., Gartner, R., Haft, M. R., Harris, R. C., Haygarth, P. M., Hedges, M. C., Hiscock, K. M., and Lovett, A. A.: Developing Demonstration Test Catchments as a platform for transdisciplinary land management research in England Wales, Environ. Sci.-Proc. Imp., 16, 16181628, 2014.

Morel, B., Durand, P., Jaffrezic, A., Gruau, G., and Molenat, J.: Sources of dissolved organic carbon during stormflow in a headwater agricultural catchment, Hydrol. Proc., 23, 2888-2901, https://doi.org/10.1002/hyp.7379, 2009.

Mulholland, P. J., Dahm, C. N., Dodds, W. K., Gregory, S. V., Grimm, N. B., Hall Jr., R. O., Hamilton, S. K., Johnson, S. L., Peterson, B. J., McDowell, W. H., Meyer, J. L.,Tank, J. L., Valett, H. M., and Webster, J. R.: Lotic intersite nitrogen eXperiment II (LINX II): A cross-site study of the effects of anthropogenic land use change on nitrate uptake and retention in 72 streams across 8 different biomes (2003-2006), Lotic Intersite Nitrogen Ex- 
periment available at: http://andrewsforest.oregonstate.edu/data/ abstract.cfm?dbcode=AN006, 2015.

Neff, J. C. and Asner, G. P.: Dissolved Organic Carbon in Terrestrial Ecosystems: Synthesis and a Model, Ecosystems, 4, 29-48, https://doi.org/10.1007/s100210000058, 2001.

Oeurng, C., Sauvage, S., Coynel, A., Maneux, E., Etcheber, H., and Sánchez-Pérez, J.-M.: Fluvial transport of suspended sediment and organic carbon during flood events in a large agricultural catchment in southwest France, Hydrol. Proc., 25, 2365-2378, https://doi.org/10.1002/hyp.7999, 2011.

Orr, R. J., Murray, P. J., Eyles, C. J., Blackwell, M. S. A., Cardenas, L. M., Collins, A. L., Dungait, J. A. J., Goulding, K. W. T., Griffith, B. A., Gurr, S. J., Harris, P., Hawkins, J. M. B., Misselbrook, T. H., Rawlings, C., Shepherd, A., Sint, H., Takahashi, T., Tozer, K. N., Whitmore, A. P., Wu, L., and Lee, M. R. F.: The North Wyke Farm Platform: effect of temperate grassland farming systems on soil moisture contents, runoff and associated water quality dynamics, Eur. J. Soil Sci., 67, 374-385, 2016.

Outram, F. N., Lloyd, C. E. M., Jonczyk, J., Benskin, C. McW. H., Grant, F., Perks, M. T., Deasy, C., Burke, S. P., Collins, A. L., Freer, J., Haygarth, P. M., Hiscock, K. M., Johnes, P. J., and Lovett, A. L.: High-frequency monitoring of nitrogen and phosphorus response in three rural catchments to the end of the 20112012 drought in England, Hydrol. Earth Syst. Sci., 18, 34293448, https://doi.org/10.5194/hess-18-3429-2014, 2014.

Parliamentary Office of Science and Technology (POST): Diffuse pollution of water by agriculture, Postnote, 478, October 2014.

Pinheiro, J., Bates, D., DebRoy, S., Sarkar, D., and R Core Team: nlme: Linear and Nonlinear Mixed Effects Models, R package version 3.1-128, available at: http://CRAN.R-project.org/ package $=$ nlme, 2016.

Prior, H. and Johnes, P. J.: Regulation of surface water quality in a Chalk catchment, UK: an assessment of the relative importance of instream and wetland processes, Sci. Total Environ., 282/283, 159-174, 2002.

Rabalais, N. N.: Nitrogen in aquatic ecosystems, Ambio, 31, 102112, 2002.

R Core Team: a languae and environment for statistical computing, R Foundation for Statistical Computing, Vienna, Austria, https: //www.R-project.org/, 2016.

Rodríguez-Cardona, B., Wymore, A. S., and McDowell, W. H.: DOC: $\mathrm{NO}_{3}$ ratios and $\mathrm{NO}_{3}$ uptake in forested headwater streams, J. Geophys. Res.-Biogeo., 121, 205-217, 2016.

Sandford, R. C., Hawkins, J. M. B., Bol, R., and Worsfold, P. J.: Export of dissolved organic carbon and nitrate from grassland in winter using high temporal resolution, in situ UV sensing, Sci. Total Environ., 456-457, 384-391, 2013.

Seibert, J., Grabs, T., Köhler, S., Laudon, H., Winterdahl, M., and Bishop, K.: Linking soil- and stream-water chemistry based on a Riparian Flow-Concentration Integration Model, Hydrol. Earth Syst. Sci., 13, 2287-2297, https://doi.org/10.5194/hess-13-22872009, 2009.

Stanley, E. H., Powers, S. M., Lottig, N. R., Buffam, I., and Crawford, J. T.: Contemporary changes in dissolved organic carbon (DOC) in human-dominated rivers: is there a role for DOC management?, Freshwater Biol., 57, 26-42, https://doi.org/10.1111/j.1365-2427.2011.02613.x, 2012.
Taylor, P. G. and Townsend, A. R.: Stoichiometric control of organic carbon-nitrate relationships from soils to the sea, Nature, 464, 1178-1181, https://doi.org/10.1038/nature08985, 2010.

Tesoriero, A. J., Duff, J. H., Saad, D. A., Spahr, N. E., and Wolock, D. M.: Vulnerability of streams to legacy nitrate sources, Environ. Sci. Technol., 47, 3623-3629, https://doi.org/10.1021/es305026x, 2013.

Thomas, Z., Abbott, B. W., Troccaz, O., Baudry, J., and Pinay, G.: Proximate and ultimate controls on carbon and nutrient dynamics of small agricultural catchments, Biogeosciences, 13, 18631875, https://doi.org/10.5194/bg-13-1863-2016, 2016.

Tiemeyer, B. and Kahle, P.: Nitrogen and dissolved organic carbon (DOC) losses from an artificially drained grassland on organic soils, Biogeosciences, 11, 4123-4137, https://doi.org/10.5194/bg-11-4123-2014, 2014.

Vitousek, P. M., Aber, J. D., Howarth, R. W., Likens, G. E., Matson, P. A., Schindler, D. W., Schlesinger, W. H., and Tilman, D.: Human alteration of the global nitrogen cycle: Sources and consequences, Ecol. Appl., 7, 737-750, https://doi.org/10.2307/2269431, 1997.

Vitousek, P. M., Naylor, R., Crews, T., David, M. B., Drinkwater, L. E., Johnes, P. J., Katzenberger, J., Martinelli, L. A., Matson, P. A., Nziguheba, G., Ojima, D., Palm, C., Robertson, G. P., Sanchez, P. A., Townsend, A. R., and Zhang, F.: Nutrient imbalances in agricultural development, Science, 326, 1319-1320, 2009.

Wang, L., Stuart, M. E., Bloomfield, J. P., Butcher, A. S., and Gooddy, D. C.: Prediction of the arrival of peak nitrate concentrations at the water table at the regional scale in Great Britain, Hydrol. Proc., 26, 226-239, 2012.

Wang, L., Butcher, A. S., Stuart, M. E., Gooddy, D. C., and Bloomfield, J. P.: The nitrate time bomb: a numerical way to investigate nitrate storage and lag time in the USZ, Environ. Geochem. Hlth., 35, 667-681, 2013.

Wang, L., Stuart, M. E., Lewis, M. A., Ward, R. S., Skirvin, D., Naden, P. S., A. L. Collins, and Ascott, M. J.: The changing trend in nitrate concentrations in major aquifers due to historical nitrate loading from agricultural land across England and Wales from 1925 to 2150, Sci. Total Environ., 542, 694-705, 2016.

Watts, G., Battarbee, R. W., Bloomfield, J. P., Crossman, J., and Daccache, A.: Climate change and water in the UK - past changes and future prospects, Prog. Phys. Geog., 39, 6-28, 2015.

Whitehead, P. G., Wilby, R. L., Butterfield, D., and Wade, A. J.: Impacts of climate change on in-stream nitrogen in a lowland chalk stream: an appraisal of adaptation strategies, Sci. Total Environ., 365, 260-273, 2006.

Whitehead, P. G., Wilby, R. L., Battarbee, R. W., Kernan, M., and Wade, A. J.: A review of the potential impacts of climate change on surface water quality, Hydrol. Sci. J., 54, 101-123, 2009.

Withers, P. J. A., Neal, C., Jarvie, H. P., and Doody, D. G.: Agriculture and Eutrophication: Where Do We Go from Here?, Sustainability, 6, 5853-5875, https://doi.org/10.3390/su6095853, 2014.

Yang, X.-L., Li, T.-K., Hua, K.-K., and Zhang, Y.-L.: Investigation of first flushes in a small rural-agricultural catchment, Pol. J. Environ. Stud., 24, 381-389, 2015.

Yates, C. A. and Johnes, P. J.: Nitrogen speciation and phosphorus fractionation dynamics in a lowland chalk catchment: the Upper Wylye, Sci. Total Environ., 444, 466-479, https://doi.org/10.1016/j.scitotenv.2012.12.002, 2013. 
Yates, C. A., Johnes, P. J., and Spencer, R. G. M.: Assessing the drivers of dissolved organic matter export from two contrasting lowland catchments, UK, Sci. Total Environ., 569-570, 13301340, https://doi.org/10.1016/j.scitotenv.2016.06.211, 2016. 